\title{
The HeART of Listening
}

Eric DeMeulenaere

\begin{abstract}
Dr. Eric DeMeulenaere is Associate Professor of Education at Clark University in Worcester, MA. When he received the Ernest A. Lynton Award for the Scholarship of Engagement in 2015, he was an Assistant Professor coming up for promotion and tenure. He received the Lynton award because his scholarly work exemplifies deep collaboration with community partners across the faculty roles of teaching, research, and service. That reciprocity and valuing of the knowledge assets in the community comes across strongly in this essay. His essay is fundamentally about engagement that disrupts the dominant epistemology of the academy, which narrowly constrains ways of knowing and passes for legitimate knowledge. Much of this essay reflects the keynote address that Eric gave at the Lynton Colloquium at the University of Massachusetts, Boston in September of 2015. He received the Lynton Award at the annual meeting of the Coalition of Urban and Metropolitan Universities in Omaha, Nebraska the following month. Scholars like Eric, and all Lynton Award recipients, need supportive institutional environments of campuses, like those of CUMU, which redefine excellence through demonstrated engagement with and positive impact across their local cities and communities, valuing and nurturing their epistemic orientations and those of their students.
\end{abstract}

—John Saltmarsh, University of Massachusetts, Boston.

Keywords: Community engagement; engaged scholarship; activist academic; youth; urban education; university-community partnerships; Ernest Lynton Award

\section{Introduction}

October 11, 2015. I had just landed this morning for my first visit ever to Omaha, Nebraska, where the next day I was going to receive the Ernest Lynton Award for community-engaged scholarship at the Coalition of Urban and Metropolitan Universities' annual conference. The following day, which also happened to be Indigenous People's Day (also known as Columbus Day), I was scheduled to give a speech in conjunction with receiving the award. Nervous about receiving the award and giving a speech, I quickly checked into my room, laced up my running shoes, positioned my earbuds and headed out for a jog on an unseasonably balmy day in Omaha. Turning north from my hotel, I passed by the ConAgra Foods headquarters, which had just announced the layoff of 1,500 employees as part of the relocation of its headquarters to Chicago. I then crossed a long walking ramp that spilled into a larger park that ran along the Missouri River. I passed historical markers that commemorated the landing of Lewis and Clark in 1804 with no real mention of how that date marked the beginning of the process of taking that land from the indigenous people in this part of the United States.

Metropolitan Universities Vol. 29 No. 2 (May 2018), DOI: 10.18060/22395 
Crossing the Bob Kerry pedestrian bridge, my eyes took in the riverfront and the view of the city skyline as my mind contemplated the Pawnee, Otoe, Sioux, Missouri, Iowa and Omaha peoples who had once lived in and controlled the land I jogged on. I thought about how the following day, a holiday celebrates the father of the American genocide and the creator of the transatlantic slave trade. I reflected on the connections between that and the speech I was planning to give about the scholarship of engagement.

\section{Forgetting}

Pausing at the middle of the bridge that connected Nebraska to Iowa, I looked north where the Missouri River curves its way up several hundred miles to North Dakota. A little ways east from the river, my grandmother grew up in a farmhouse in Spiritwood, North Dakota. Several years before my grandmother was born, my great grandfather was able, because of his European heritage, to obtain land free through the Homestead Act-land that was forcibly stolen from the Dakota who had lived there. The Homestead Act, and the Preemption Act before it, encoded into federal policy the racist ideology of Manifest Destiny. No history records the destruction of the human lives of Native Americans that these actions created for the families that were living where my great grandfather "homesteaded" in North Dakota. Historical markers in Omaha never mention the treaties and small pox that stole the land from the American Indians. Columbus day parades ignore the mutilated and enslaved bodies of Americas’ First Nations. My own family history records for me that this "gifted" land enabled my great grandfather to raise 18 children, including my grandmother, all of whom survived through the Great Depression. My great uncle was even able to use the profits from the farm to buy the land from his seventeen siblings. That very small nest egg would later support my grandmother's move west. She eventually settled in California, marrying and buying a small house.

My legacy dates not only to the quaint little farmhouse in Spiritwood, North Dakota that we visit for family reunions; it is linked to the legacy of stolen land and the oppression of Dakota families. I stand here today as a legacy of the "exploration” by Louis and Clark and the "discovery" of Columbus. I am thankful to Christine Sleeter (2008) whose own efforts to think critically about her genealogy inspired me to look critically at my own genealogy and refuse to allow my family to continue to ignore our history of privilege. Professor Sleeter helped me to recognize that it is not only important for me to humbly recognize that I stand before you today on the shoulders of my strong and stoic grandmother, but also that I simultaneously stand on the heads of the Dakota families whose stolen lands are similarly tied to my own legacy.

Standing on the bridge over the Missouri River thinking about histories ignored, I recalled Ta Nehisi Coates' (2015) haunting book, Between the World and Me. There, he reminds us of how easy it is for those of us who inhabit spaces of privilege, to forget. He writes:

The forgetting is habit, is yet another necessary component of the Dream. They [white people who he refers to as "dreamers"] have forgotten the scale of theft that enriched them in slavery; the terror that allowed them, for a century, to pilfer the vote; the segregationist policy that gave them their suburbs. They have forgotten, because to remember would tumble them out of the beautiful Dream and force them to live down here with us, down here in the world. I am convinced 
that the Dreamers, at least the Dreamers of today, would rather live white than live free.... To awaken them is to reveal that they are an empire of humans and, like all empires of humans, are built on the destruction of the body. It is to stain their nobility, to make them vulnerable, fallible, breakable humans (p. 143).

Ta Nahisi Coates chilling words demand I remember that my successes come at a cost to others.

Jogging back towards my hotel with Coates words mingling with Indigenous People's Day and the Dakota Nation, I recalled Franz Boas and his work with Ella Deloria. While in graduate school, I studied under several anthropologists, but it was only when I arrived at Clark University as a new assistant professor of education that I first heard about Frank Boas-the father of American Anthropology. His first academic appointment was in 1888 at the then newly formed Clark University. The more I learned about Boas, the more I came to admire his work and connect with his disposition toward this work. He wrote in 1884 to his then-future wife:

I do not want a German professorship because I know I would be restricted to my science and to teaching, for which I have little inclination. I should much prefer to live in America in order to be able to further those ideas for which I live.... What I want to live and die for, is equal rights for all... Don't you believe that to have done even the smallest bit for this, is more than all science taken together?

I, too, never sought to be an academic. Even after earning my Ph.D. in Education in 2003, I worked to open a school for social justice in Oakland, CA. I wanted to be involved in the creation of radical social change and the academy seemed too distant and removed from this work. At the time, I had not yet encountered academics like Franz Boas, or Ernest Lynton, or John Saltmarsh. Instead, after getting my doctorate, I worked with others to create a small school for social justice in Oakland modeled after the school the Black Panther Party had created decades earlier. When the state of California took over the Oakland Unified School District and appointed the second state administrator, they began to target the new small schools for closure. My school was one of the first targeted and shut down. I felt defeated. I did not know what to do. My mentor and fellow community activist, Margo Okazawa-Rey, said that being an academic is the perfect job for an activist. You control your time and the projects on which you work. With the discovery of participatory action research, I learned that my research could be a part of my activism. I have been spending the last several years trying to figure out how to make my work as an academic, the same as my activist work-how to marry my scholarship, teaching and service as an academic to my vocational commitment to social justice-what it means to be an activist academic ${ }^{i}$. This article offers my reflections on this journey-of learning to remember and listen.

\section{Remembering}

On this journey, I have been fortunate to encounter many role models. More than hundred years ago, Franz Boas' scholarship worked to challenge the Social Darwinism and Eugenics that were the dominant, and racist, ideologies of his day. However, beyond his prolific and diverse scholarship, he simultaneously worked closely with W.E.B DuBois to found the NAACP. He wrote prominently for the NAACP's recently launched Crisis magazine. He supported Carter G. 
Woodson's efforts to create Black History Week and worked tirelessly, albeit unsuccessfully, to launch an African American Museum in New York.

But mostly, he worked to remember, not just the forgotten horrors committed by White people, but to reclaim the hidden stories of the greatness of Black people and American Indians. W. E. B. Dubois brought Boas to Atlanta University to give the commencement speech in 1906. About this speech, DuBois (1939) wrote,

Franz Boas came to Atlanta University where I was teaching history in 1906 and said to a graduating class. You need not be ashamed of your African past; and then he recounted the history of the black kingdoms south of the Sahara for a thousand years. I was too astonished to speak. All of this I had never heard and I came then and afterwards to realize how the silence and neglect of science can let truth utterly disappear or even be unconsciously distorted (p. vii).

In all his work Boas challenged the ideas of exceptionalism of European cultures - the prevalent ethnocentric idea that European and White American culture was somehow more civilized, more evolved, than other cultures. One of the ways he did this, which resonates with my own work was by nurturing and raising funds for what Antonio Gramsci would later call organic intellectuals from the subaltern-intellectuals from marginalized groups who communicate ideologies that disrupt the dominant narratives. Boas, for example, supported and collaborated extensively with Ella Deloria, a multilingual Dakota woman. He sought out funding for her research into the Dakota culture and they collaborated on several research projects and even wrote a book together. He similarly supported Zora Neale Hurston in very much the same way. Interestingly, both Hurston and Deloria ended up becoming more famous for their fiction that grew out of their ethnographic, folkloric, and linguistic work, writing that was encouraged by Boas. As I have recently earned tenure, this raises all kinds of questions for me about how I as an academic should best communicate my research, how I write, and where I publish. I deeply appreciate Boas for his model of supporting the development of organic intellectuals like Hurston and Deloria.

Antonio Gramsci (2005), the Marxist revolutionary imprisoned by Mussolini, and one of my intellectual forbearers, argues that everyone is an intellectual, only some of us are public intellectuals, paid to work in the field of ideas. He states that everyone "carries on some form of intellectual activity,... participates in a particular conception of the world, has a conscious line of moral conduct, and therefore contributes to sustain a conception of the world or to modify it, that is, to bring into being new modes of thought” (p. 51). Most public intellectuals, Gramsci argued, view themselves as distinct from the structures that create and maintain social inequities, but are, in fact, complicit in those systems. Gramsci's analysis causes me to question, repeatedly, my positioning. Gramsci called for the rise of new counter-hegemonic intellectuals who would come either from marginalized groups like Deloria and Hurston, or from traditional public intellectuals who are converted to work to transform the ideological and material conditions that maintain inequality. These new counter-hegemonic intellectuals, Gramsci asserted, "can no longer consist in eloquence ... but in active participation in practical life, as constructor, organizer, 'permanent persuader' and not just a simple orator" (Gramsci, 1971, p. 10). In other words, these new transformative intellectuals cannot simply offer revolutionary ideas removed from concrete 
participation in the lives of the people for whom they advocate liberation. Gramsci's words constantly push me to reflect, always, on my practice.

\section{Crossing Main Street}

In my second year at Clark, I became involved in a project co-teaching a group of high school seniors at a local public high school a few blocks from Clark's campus. One aspect of the course had our high school seniors collaborating with students in my colleague's First Year Intensive course at Clark University. The idea was that they would work together to make art and at the end of the semester we would curate together a professional art exhibition.

On the first day we brought the two afterschool classes together, we put them into groups of six with a couple students from each class and gave each group a camera. We told them to go out into the community and capture pictures that represent their ideas of "self," "home," "community," and "dreams." One of the groups headed out and a couple of the young college students suggested going across Main Street in front of Clark's campus to get a soda at a small market. One of the high school students, Lionel ${ }^{\mathrm{ii}}$, hedged and said he did not want to go over there. The college students offered to pay for his soda, thinking money might be the reason for the hesitation. Lionel kept hesitating stating vaguely that there could be trouble if he went there. The college students did not take him seriously. It is right across the street from campus, how would he get involved in any fight right across the street in the middle of the day. What he never told them is that he had not been across Main Street in five years. He was involved with a gang that had a long-standing feud with another gang that controlled the territory across Main Street. Despite this complication, Lionel allowed himself to be talked into crossing the street by these college students - students he had just met and who were barely a year older than he was.

Against Lionel's better judgment, he and his group crossed Main Street and headed towards the store. Sure enough, some youth from the rival gang saw him. They got on their cell phones, and in no time, a group of youth began to approach Lionel and the group of students with him. Once words passed between them, Lionel made it clear, he was ready to stay and fight a whole group of other youth. Somehow, the Clark students and Lionel's classmates talked him into leaving and they all raced across the street and into one of Clark's science buildings where the rival gang members followed them and waited outside. I found out about this after the students called my co-teacher who drove up to the back of the science building to sneak them out and drive them to a safer place.

There are several ways to analyze this story. First, the episode reveals an entire social reality that literally crosses through my college campus and directly shapes the lives of several neighborhood youth that remains hidden from the social world of our college community. Indeed, the young people caught up in this world are so sophisticated that they know, always, which person are Clark students and which youth are from the neighborhood. Sure, Clark students experience the occasional mugging. However, they live far apart from much of the violence that occurs in our Main South neighborhood. Moreover, most Clark students and faculty remain completely oblivious to this reality. This experience was a powerful learning moment for my college students. 


\section{Real University-Community Engagement}

However, the main reason I share this story is that it serves as a powerful metaphor for community-engagement work in universities. Too often, in so many university projects that work to collaborate with the community, the people who learn the most, who benefit the most are the college students. The college students in this situation meant well, but they were just unaware. We might wish to forgive them because they really had no idea what was going on. Nevertheless, their ignorance did not create the problem, but rather their inaccurate interpretation of the situation, exacerbated by their inability to listen to Lionel.

They responded based on their understanding of the world and made assumptions rooted in the best of intentions. If they had just listened to Lionel and had not made assumptions about his resistance to go to the store, they might have all avoided danger. Problems occur when people come from the academy, or other spaces of privilege, assume they understand the problem and offer the solution. Teju Cole (2013) referred to this tendency as the "white-savior industrial complex." Cole suggested that rather than attempt to save people, "why don't you ask the people you're trying to save what it is that they need?” (as quoted in Alfaro, 2015). People from spaces of privilege too frequently create danger or bring harm because they too easily trust their assumptions and fail to listen effectively. Yet if we can learn to listen, we might just receive the knowledge that can keep us all safe.

\section{Community-Making Sense of Social Reality (-ies)}

Now I want to turn and analyze Lionel in this situation. Before I do, I want to share a little bit more information about him. What I have shared so far is that Lionel was involved with a local gang. That is it, and we have all kinds of stereotypes about gangs in this country. These stereotypes were at play in the high school where I taught Lionel. One of his classmates wrote her college essay on what she learned from Lionel in our class. She wrote in part:

I tried to stay as far away as possible from the "Lionel's" at my school .... I was college bound, while he was headed for jail. I became the smart Asian girl who everyone believed in, while Lionel became the deviant that society wanted to ignore.... Our paths collided when Lionel and I were put in a group that had the tasks of carrying an open 5-gallon container of water, an uncooked egg, and ourselves up to the top of a mountain. Lionel became a leader. He encouraged everyone, including my friend Jenny who was struggling to make it up the hill. Lionel walked with her for the final section of the trail to make sure she didn't trip or fall behind. For the majority of the hike, he carried the five-gallon water bottle.... Everything I was taught to believe about Lionel dissolved into the victorious feeling of being on top of the mountain and we wouldn't have made it there without him. From the top of the mountain, I... began to see myself and the people I grew up with in a new light.

This is always how it is. The upper-tracked students are usually oblivious to what is happening in the lower tracks, but the lower-tracked students are much more aware. It is always easier for those most oppressed to develop critical consciousness. 
I remember later in the class with Lionel, we were reading chapters from Foucault's (1977) Discipline and Punish. At around the same time, I also had students in my undergraduate college class reading the same chapters. The high school students struggled with (and whined and complained about) the dense language of the text. We had to slow down and spend a lot more time trying to make sense of what Foucault was saying. However, once they comprehended Foucault's concepts of docile bodies, hierarchical observation, the examination and the Panopticon, there was a very different reaction to the social theory from the high school students than from my college undergrads. The connections Foucault makes between prisons, factories, the military and schools comes alive when you are teaching it to kids who have been in jail, worked in factories and have family in the military. These students hated trying to decipher the dense text, but they loved the theory-it gave them a language to talk about and make sense of something they already knew deep in their bones. Most good theory does not offer new information per se, rather it gives a language and a way to organize what people know intimately from their lived experience. This experience of social theory that my high school students had mirrored bell hooks (1994) and her embrace of theory:

I came to theory because I was hurting - the pain within me was so intense that I could not go on living. I came to theory desperate, wanting to comprehend-to grasp what was happening around and within me. Most importantly, I wanted to make the hurt go away. I saw in theory then a location for healing (p. 59).

I used to be puzzled over why most of my undergraduate students did not appreciate good theory and preferred the more narrative texts I assigned. It was because most of my undergraduates did not really need it in the same way. They were not struggling to make sense of their social reality. They were not in pain, trying to find healing. However, for the marginalized and oppressed, for the students in my high school class, they approached social theory as an ointment for healing. We have all these amazing social theorists in our urban schools who are turned off by schooling, by what Paulo Freire (1970) calls banking education. They reject schooling not because they are lazy, not because they are not intellectual; rather they reject a system that does not help them to develop as organic intellectuals, that does not enable them embrace theory to heal and make sense of their social reality. The best educators in urban schools recognize that the kids with heart, the youth willing to walk out of a class or tell off a teacher, are those very students who possess a critical consciousness about their social reality. They are also the students who feel the pain of oppression most deeply. Michelle Fine (1991) discovered this decades ago in her work examining high school dropouts. She writes:

The dropout was an adolescent who scored as psychologically healthy. Critical of social and economic injustice, this student was willing to challenge an unfair grade and unwilling to conform mindlessly. In contrast, the student who remained in school was relatively depressed. Self-blaming, this student was more teacherdependent, unwilling to challenge a misgrade, and endlessly willing to conform. By the end of this research, I worried about those who left public high school; but I also worried about what we instill in those who remain (p. 4). 
Lionel was this type of student. He is brilliant. He is a leader. However, he was barely passing school, and he hated school. One time when we presented together in a college class, Lionel told a story from second grade. He had been suspended for cursing at a teacher. When he came back from suspension, they had created a behavior plan for Lionel. Every day he went without getting in trouble, he earned a candy bar. He started collecting the candy bars and began selling them to his classmates and kids on the streets for spending money. For him, even as early as second grade, schooling was ridiculous.

So much of our success in teaching that class of seniors we owe to Lionel. Because he took our class seriously, so many of his classmates followed his lead. Also, the high-tracked students in the class came to realize that their assumptions about the difference between the educational tracks had to be challenged. They came to recognize that nothing special separated the students in the different tracks. In many ways, Lionel brought qualities that were missing, qualities like courage and a sense of self. When I started out as a teacher, everyone wanted to teach the juniors and seniors. However, I later came to realize that that was because by $11^{\text {th }}$ and $12^{\text {th }}$ grade, the kids with heart had usually left. Those were the easiest grades to teach because the students who persisted that long were the docile bodies who would tolerate the banking educational system. Moreover, we need the Lionel's in our lives - the courageous disrupters, the challengers of authority. There is a reason why Paulo Freire puts his faith in the oppressed when it comes to creating the radical social change we need in this society.

Lionel was fearless, not only on the streets, but in dealing with teachers and honors kids and even college admission counselors. He wrote with this raw, authentic and powerful voice. This is how he started his college essay:

I wonder how it feels to decide a college applicants' fate. I see college admissions officers as caring most about building the reputation for their college. Do not 4.0 GPA's and perfect SAT scores boost the competitive status of universities? Forget about the kids from the ghetto when the selectivity index is on the line, right? How can ghetto kids help your ranking in the US News and World Report's annual guide to selective colleges? Isn’t that your job, to serve the best interests of your college? I suppose you just need to do your job so you can make your money to support your family, your mortgage and your nice car in the driveway. You are really living, I guess, but you deserve it. I mean you have worked hard for all you have, right?

I recognize that I just unfairly labeled you and I apologize for that. But I am tired and angry of all the unfair labeling that happens all the time to me and the people in my neighborhood. My transcript may not properly reflect it, but I, too, know what hard work means. I work daily from 3:00 pm to 3:30 am and then wake up at 6:00 am to go to school. It is hard taking a van filled with immigrants to work at the Frito-Lay factory earning only seven dollars an hour, when I actually deserve much more.... I'm not asking for you to feel bad for me or the kids I used to live with in the projects. I am only asking for the same shot that you give the rich kid with the Mercedes Benz and the private tutors. 
Let us return to the scene where Lionel followed the college students across the street. It is really interesting that Lionel, a young man with such heart, who seems to be able to stand up to anyone, was somehow compelled to cross Main Street by a few college freshmen, who were sheltered and naïve about the realities of city life generally, and Main South Worcester in particular. What is it that caused Lionel to deny the knowledge that would have kept him and everyone safe?

I saw this silencing every time we brought the high school students together with the college students. The high school students, who usually had a lot to say, remained relatively quiet. One time we watched a documentary film together called AKA Don Bonus, which was about a Cambodian refugee growing up in housing projects in San Francisco and struggling to survive and graduate high school. The film provoked an interesting discussion, mostly with the college students speaking. My co-teacher asked the question, is Sokly Ny (AKA Don Bonus) smart? Should he gain admission to Clark?

The high school students stayed quiet, but the college students dutifully responded, "Maybe he wouldn't have wanted to go to college." One student ventured, "I am not sure he would like college.” Another added, “I don't think he would have the discipline needed to go to college. I mean it would suck for him to be admitted and then fail out."”

The high school students did not offer many responses to this question, but the next day before class, one of the high school students shared with me how upset he was with the Clark students. Actually, he became upset at the entire college system. He identified strongly with Sokly Ny and he was angry because he felt that the college students dismissed his own college ambitions. I remember him stating something like, "I think everyone should get a chance to go to college and try to make it there. This system is so screwed up."

He had pretty much messed up through high school, getting horrible grades. Now, in part because of our course, he was really re-thinking his future and wanted to go to college. He was smart and knew he could go and do well at Clark, but he also knew his past grades would prevent him from being accepted. He was so enraged. I asked, “Why didn’t you say anything yesterday to the group?” He answered, “I don't know, I didn’t know what to say....”

The collaboration was powerful in several ways. My high school students slowly began to realize that the college students were no smarter than they were. Halfway into the semester, the high school students shared their memoirs with the college students who shared their college statements. Several of the college students expressed surprise at how powerful the memoirs were. This simultaneously made the high school students a little proud and angry for the fact that the college students had not expected them to write powerfully. However, most of the high school students did not express that to the college students. The college students felt positive about the collaboration for the entire semester. And there were a lot of wonderful moments together. Again, the college students were completely oblivious to the simmering frustrations that many of the high school students felt throughout the collaboration. I kept pushing the high school students to speak up. 


\section{Where is the "we"?}

Finally, at the end of the collaboration, as we were preparing for the art show in December, the high school students found their voice, again led by Lionel. We were planning an art exhibit to display the masks, artist books and the photographs we had all created together as a collaborative art exhibition between the high school and college students. We had taken over 500 photographs. We planned to have a small group of college students join a small group high school students to work with a professional photographer to select about a hundred photos taken in the Main South community. Of these hundred, the entire group would narrow it down to fifty for the exhibition. However, due to some drama at the high school, its leadership cancelled all afterschool activities the Wednesday when the initial selection team was supposed to meet. Therefore, only the college students went with the photographer to select the 100 photos. The deadline with the printer meant we could not delay it another week. The following Wednesday we met as a large group to select 50 photographs from the 100 chosen by the group of college students working with the photographer. This group of college students got up at the meeting along with the professional photographer and started to talk about each photograph as they flashed the photograph across a large projection screen. The college students from the selection group would share why they chose each photo. The professional photographer and his assistant talked about the composition of the photographs. The process began initially with everyone encouraged to raise their hand if they wanted the image in the show or not. Initially, there was only limited and rather pleasant discussion before the vote on any particular photograph.

A small group of the high school students, led by Lionel, became more and more vocal with each passing slide. Finally, one of them said, "These photos are too nice of the neighborhood. That's not the Main South I know!”

Another exclaimed, "We have two different visions. You all,” meaning the college students, "see the neighborhood different than us.” Lionel and his friends kept asking who took each picture, not wanting to support photos that the college students had taken. The discussion began to devolve and it was hard to reach any real conclusion about what to do. The real, albeit unspoken issue, was who really has the authority to say what photos best represents the community - the high school students who lived their entire lives in Main South or the college students who recently arrived? Some of the high school students finally unleashed their voices, probably channeling some of the dormant frustrations, and said some things that were hurtful to the college students.

Many of the college students felt the high school students dismissed their perspectives. Several of the college students articulated a position that indicated that, although they had a different perspective on the community, that it was just as legitimate. They also argued that the point of this art exhibition was to highlight the collaboration across differences and excluding anyone from the choosing was not collaborative. The debate raged on for a while and we were clearly not completing the task to choose fifty pictures. The conflict eventually ended when one of the high school students said that everyone should just pick one photo and explain why they chose it. People left frustrated and hurt. 
The whole debate seemed to divide the high school students from the college students. In the end, the high school students continued to assert their voice by formally naming the exhibition, "Us and Them." The college students and the teachers I was working with were not so excited about this and the title itself became hotly debated and contentious. The conflict saddened many people involved in the project. I was probably the only one that felt good that a more honest dialogue had begun, but unfortunately, it was at the very end of the collaboration. This was the first time that there was intense passion in the conversation in which people were really trying to speak their truth to each other across the differences. The college students had felt that the collaboration had been going smoothly throughout the semester and were shocked and saddened by the hostility and conflict that occurred, which they felt had undermined all the progress they thought they had made.

I, conversely, felt like it was really the beginning of authentic dialogue. The prior pleasantness of the interactions and lack of conflict really hid the underlying frustrations concealed by the general silence of the high school students. Now they were struggling with what the community really was and how to represent it. This was messy and contentious stuff. Finally, the college students could see what the high school students, who had been silent for so long, really thought, and the high school students began to find their voices. I felt the learning had really begun, albeit very late in the collaboration.

My lifelong work has been about getting youth to speak with powerful voices. The high school students I have worked with are big fans of Tupac Shakur. Many years ago, one of my students gave me a book of poems Tupac had written. One of them is "The Rose That Grew From Concrete.” It goes like this:

Did you hear about the rose that grew from a crack in the concrete? Proving nature's law is wrong it learned to walk without having feet. Funny it seems, but by keeping its dreams, it learned to breathe fresh air. Long live the rose that grew from concrete when no one else ever cared (Shakur, 1999, p. 3).

Too often, instead of seeing roses that grew through concrete, our society focuses on the messed up petals, how the leaves are not perfect. Teachers in urban schools complain about the sharp thorns, but fail to recognize that thorns grow for protection. These narratives are so dominant that my youth, my roses, come to see themselves as flawed, embarrassed by their petals. Their stories have taught me that I can never assume I understand anything from looking at the petals or the leaves or the thorns. Assumptions are dangerous. What matters is the story of how they came to blossom at all. I have learned that I need to listen more and create the space for youth to share their stories. These counter-stories help youth see that their rose petals are their greatest strength, and this should not embarrass them. Counter-storytelling is not only healing, it can be transformative, not just for the youth, but also for the rest of us.

Back in Worcester, I lace my jogging shoes up and head out for a run. As I cross Main Street, I remind myself of Lionel's lesson about the turf boundaries to which I am mostly oblivious. Lionel has helped me become more mindful not only of what remains oblivious to me, but to the many ways my privilege pushes me to forget and blinds me to the realities right in front of me. 
Lionel has taught me that if I really want to understand, to remember, and to have any type of impact, I really need to let go of my assumptions and listen.

I no longer try to help young people fit into college, because they should not fit in, they should lead the transformation needed on our campuses. Indeed, I am not trying to help the youth in Worcester at all, rather I am privileged to be able to work with them, beside them, behind them and watch them develop into the organic intellectuals we need to disrupt the dominant narratives and envision a new society. Much like Lionel held the knowledge that would keep his group safe, we need the Lionel's in our world to guide us through the dangers of our time and remind us about the stories we have forgotten, the stories that can set us all free. I will let Lionel have the final words, words from later on in his college statement:

I have come to believe that it is important for my voice to be heard, and through an education at your college, this just might be possible. You might be worried about how my admission will put your college's competitive stature in jeopardy. Please trust me, while my academic record is far from perfect, I am aware of the task before me and I am up to the challenge. Sure, I am a kid from the ghetto, but I am becoming a young man who is willing to speak the truth and make a difference in this world. 


\section{References}

Alfaro, M. (2015, April 24). Novelist Teju Cole discusses ‘white-savior industrial complex' for packed audience. The Daily Northwestern. Retrieved from:

http://dailynorthwestern.com/2015/04/24/campus/novelist-teju-cole-discusses-white-saviorindustrial-complex-for-packed-audience/

Cole, T. (2012). The white savior industrial complex. The Atlantic, 21(March).

Coates, T. N. (2015). Between the World and Me. New York, NY: Spiegel \& Grau.

DuBois, W. E. B. (1939). Black Folk Then and Now. New York, NY: Henry Holt \& Co.

Fine, M. (1991). Framing dropouts: Notes on the politics of an urban high school. Albany, NY: State University of New York Press.

Foucault, M. (1977). Discipline and Punish: The Birth of the Prison. New York, NY: Pantheon.

Freire, P. (1970). Pedagogy of the oppressed (MB Ramos, Trans.). New York, NY: Continuum.

Gramsci, A. (2005). The Intellectuals. In S. P. Hier (Ed.), Contemporary Sociological Thought: Themes and Theories (pp. 49-57). Toronto, Ontario: Canadian Scholars' Press.

Gramsci, A., (1971). Selections from the Prison Notebooks. New York International Publishers, hooks, b. (1994). Teaching to Transgress: Education as the Practice of Freedom. New York, NY: Routledge

Shakur, T. (1999). The Rose That Grew From Concrete. New York, NY: MTV Books.

Sleeter, C. (2008). Critical family history, identity, and historical memory. Educational Studies, 43(2), 114-124. https://doi.org/10.1080/00131940801944587 


\section{Author Information}

Dr. DeMeulenaere earned his M.A. (1999) and Ph.D. (2003) in the Social and Cultural Studies Program at the University of California at Berkeley's Graduate School of Education. His dissertation research focused on urban students' transformations of their academic identities and school performances. Dr. DeMeulenaere joined Clark University's Education Department from the San Francisco Bay Area, where he was involved in urban education for sixteen years. Dr. DeMeulenaere taught middle and high school social studies and English in Oakland and San Francisco for eight years. He also served as an adjunct professor in Education at the University of California at Berkeley, the University of San Francisco and San Francisco State University. More recently, he was the co-founder and principal of an innovative small high school in East Oakland focused on social justice.

Eric DeMeulenaere

Associate Professor, Urban Schooling, Department of Education

Jacob Hiatt Center for Urban Education

Clark University

Worcester, MA 01610-1477

Telephone: 508.421.3750

Email: edemeulenaere@clarku.edu

i This, The Activist Academic, is the title of my forthcoming book co-authored with Colette Cann.

ii All names are pseudonyms. 